\title{
Design i wielofunkcyjność nowoczesnych przestrzeni bibliotecznych
}

STRESzCzEnIE: Misja i funkcja bibliotek zmieniała się na przestrzeni wieków. Obecnie oferta biblioteczna kierowana jest do szerokiego grona odbiorców. Współczesne placówki są najczęściej kreatywnymi miejscami rozwoju i zdobywania wiedzy, które inspirują i zachęcają do wizyt. Wpływ na ich rosnącą popularność ma w dużej mierze i ciekawy design, i wielofunkcyjność ich przestrzeni. W ostatnich latach kwestie te stały się przedmiotem ciekawej dyskusji na portalach bibliotekarskich, blogach, a przede wszystkim w fachowej literaturze zarówno krajowej, jak i zagranicznej. Podejmowany przez autorkę temat ma przybliżyć czytelnikowi nowe trendy w zakresie aranżacji przestrzeni bibliotecznej. Artykuł wskaże odpowiedzi na pytania, skąd czerpać wiedzę na ten temat; jak biblioteki powinny dostosowywać swoje usługi do wymagań czytelników; jak kształtować wielofunkcyjną przestrzeń, by była atrakcyjna; jaka jest rola bibliotekarza w procesie przygotowania i realizacji inwestycji? Dla przykładu, celem ilustracji, przywołano kilkanaście bibliotek o ciekawym wyposażeniu, a także architekturze, które zyskały światowe uznanie. Głównym zamierzeniem artykułu jest zwrócenie uwagi na rolę designu w budowaniu atmosfery i umacnianiu więzi na linii bibliotekarz - czytelnik, jak też na zmianę, jaka zaszła w ostatnich latach w kwestii postrzegania bibliotek, które stały się wielofunkcyjnymi ośrodkami, inspirującymi i zapraszającymi do częstych odwiedzin.

\footnotetext{
* Absolwentka historii na Uniwersytecie Warszawskim.
} 
SŁOWA KLUCzowE: budownictwo biblioteczne, design, przestrzeń biblioteczna, użytkownicy.

\section{Wprowadzenie}

Ostatnie lata przyniosły wzrost popularności designu, który święci triumfy na całym świecie. Samo pojęcie jest bardzo szerokie, np. dla grafika webowego będzie to projekt strony, dla architekta zaś architectural design. A może to być także design biblioteczny. „Nie ma współcześnie obszaru życia społecznego, gdzie intuicyjnie rozumiany design - plan, projekt, zamiar, intencja, planowanie, projektowanie - nie byłby istotnym czynnikiem w kształtowaniu ludzkiego doświadczenia"2. Wobec tego musi też znaleźć odzwierciedlenie przy projektowaniu wielofunkcyjnych przestrzeni bibliotecznych. Nowocześnie zaprojektowane biblioteki są niepowtarzalne, w projektach tych nie ma rutyny, każdy jest inny, czym innym przyciąga i zachwyca użytkowników. Jednak placówki te nie mogą być tylko piękne, powinny być także funkcjonalne, w przeciwnym bowiem razie czeka je krótki żywot. Ciekawy design ma pomóc w budowaniu atmosfery i umacnianiu więzi na linii biblioteka - czytelnik. By tak się stało, projektant musi zadać sobie szereg pytań: „kim taki użytkownik jest, jak się zachowuje, co lubi, a czego nie, co zwróci jego uwagę, a czego nie zauważy, co będzie go satysfakcjonowało, a czego nie zaakceptuje"3. Design w dużej mierze to sztuka słuchania, obserwacji oraz kreatywnego myślenia. Dopiero wtedy powstanie produkt, w tym przypadku nowa przestrzeń biblioteczna, który spełni oczekiwania lokalnej społeczności i na trwałe przyciągnie ją do swoich wnętrz.

Obecnie projektanci i architekci mają dostęp do bogatej literatury ukazującej niekonwencjonalne rozwiązania w zakresie kształtowania przestrzeni bibliotecznej. W tym miejscu warto zwrócić uwagę na kilka najciekawszych tytułów, które ukazały się w ciągu ostatnich dwóch lat. Godne uwagi publikacje to: Alex Johnson, Improbable Libraries: A Visual Journey to the World's Most Visual Libraries; Carles Broto, Libraries In-

2 M. Rosińska, Przemyśleć u/życie: projektanci - przedmioty - życie społeczne, Warszawa 2010, s. 21.

3 Tamże, s. 137. 
novation and Design; Manuela Roth, Masterpieces: Library Architekture + Design; Rebecca T. Miller, Barbara A. Genco, Better Library Design: Ideas from Library Journal; Nolan Lushington, Wolfgang Rudorf, Libraries: A Design Manual. Szersza literatura przedmiotu została wskazana w bibliografii.

Współczesne oblicze świątyń kultury, jakimi są dzisiejsze biblioteki, doskonale pokazują przywołane w tekście przykłady najciekawszych aranżacji wnętrz i architektury bibliotecznej. Ich ostateczny kształt jest najczęściej odbiciem panujących w momencie realizacji projektu trendów w dziedzinie designu, zarówno jeśli chodzi o wyposażenie, jak i bryłę budynku. Ciekawie zaprojektowane i wielofunkcyjne przestrzenie są o wiele chętniej odwiedzane niż tradycyjne placówki, które ograniczają się do jednej aktywności, jaką jest tylko i wyłącznie wypożyczanie książek. Bibliotekarze w obliczu cyfryzacji wymyślają zdumiewające sposoby, aby zachęcić czytelników do częstszych wizyt. Biblioteki fascynują więc nie tylko wiedzą zawartą w pomieszczonych tam tomach, lecz również charakterystyczną atmosferą, na którą - śmiało można powiedzieć - wpływa ciekawy design. Należy też pamiętać, że dzisiejsze placówki przyciągają czytelników również swoją wielofunkcyjnością.

Celem artykułu jest zwrócenie uwagi na design współczesnych bibliotek i jego rolę w umacnianiu więzi z użytkownikami. Stawiane w tekście pytania odnośnie do sposobu kształtowania wielofunkcyjnej przestrzeni, zadań bibliotekarza w procesie projektowania, rodzaju usług oferowanych czytelnikom - są jednymi z wielu, jakie pojawiają się, kiedy zaczynamy zastanawiać się nad problematyką nowoczesnych bibliotek i ich przestrzeniami.

\section{Design nowoczesnych bibliotek}

Gmachy projektowane z myślą o przeznaczeniu ich wyłącznie na cele biblioteczne to pomysł XIX-wieczny ${ }^{4}$. Wraz z rozwojem technologicznym i zmianami oczekiwań użytkowników następowało na przestrzeni wieków przeobrażenie ich wizerunku, szaty zarówno zewnętrznej, jak i wesz. 347.

${ }^{4}$ Encyklopedia wiedzy o książce, kom. red. A. Birkenmajer [et al.], Wrocław 1971, 
wnętrznej. Początkowo biblioteki były otwarte, nie oddzielano pomieszczeń użytkowych od magazynów. Dopiero w 1816 r. włoski architekt Leopoldo Della Santa wprowadził podział na strefę dla czytelników, personelu i księgozbioru ${ }^{5}$. Zasada ta - określana mianem klasycznego trójpodziału funkcjonalnego - stanowiła przez długi czas podstawę kanonu budownictwa bibliotecznego ${ }^{6}$. W latach 30 . XX w. zaczęto przywoływać koncepcję biblioteki otwartej, umożliwiającej czytelnikom bezpośredni kontakt z księgozbiorem, najpierw w Stanach Zjednoczonych, a później w Europie. Konieczność zmiany narzuciło m.in. rozpowszechnienie czytelnictwa i rozwój rynku wydawniczego. Miało to niewątpliwie wpływ na architekturę biblioteczną. W 1933 r. Angus Snead Macdonald opracował nowe rozwiązania konstrukcyjne dla bibliotek. Zakładał, że nowoczesne budynki powinna cechować giętkość, zmienność, przystosowalność w zależności od potrzeb użytkowych.

W XX w. biblioteki wraz z postępującą cyfryzacją zaczęły zmieniać swoje oblicze, zarówno wewnętrzne, jak i zewnętrzne. Od 1994 r. projektanci nowych obiektów w sferze konstrukcji, technologii i architektury wnętrz zaczęli wykorzystywać zasady opracowane przez brytyjskiego architekta Harry'ego Faulkner-Browna7. Nowy wiek przyniósł kolejne wytyczne. Ich autorem był Andrew McDonald, który nie odrzucając zasad H. Faulkner-Browna, zauważył, że wraz z upływem czasu zaczęto inaczej postrzegać budownictwo biblioteczne ${ }^{8}$.

Przedstawione przez niego cechy dobrze zaprojektowanej przestrzeni bibliotecznej to parametry ważne dla nowych i modernizowanych budynków bibliotecznych, dopasowane do nowej ery edukacji i informacji, z uwzględnieniem zmian społecznych, technologicznych oraz kierunków w architekturze 9 .

${ }^{5}$ L. Della Santa, Della construzione e del regolamento di una publica uniwersale biblioteca con la pianta dimostrativa, Firenze 1816.

${ }^{6}$ Zob. Bibliotekarstwo, pod red. Z. Żmigrodzkiego, Warszawa 1998, s. 28.

7 Zob. H. Faulkner-Brown, Factors affecting the planning and design of academic libraries, Speakers' notes for The British Council Seminar, [w:] Library planning and design, Newcastle upon Tyne, 11-24 Sept. 1994.

${ }^{8}$ Zob. A. McDonald, The Ten Commandments revisited: The Qualities of Good Library Space, "LIBER Quarterly: The Journal of European Research Libraries", Vol. 16: 2006, Iss. 2.

9 Bibliotekarstwo, pod red. A. Tokarskiej, Warszawa 2013, s. 683. 
Nowoczesne biblioteki tworzone w myśl tych zasad - czy to od nowa, czy też w wyniku architektonicznego recyklingu - stają się miejscami, które przyciągają wyjątkową atmosferą. Obecnie projektanci rezygnują z przepychu na rzecz wprowadzania rozwiązań sprawiających, że otoczenie nie dekoncentruje użytkowników, ale zapewnia im warunki efektywnej pracy ${ }^{10}$. Jednak, aby architektom udało się stworzyć dobry projekt, musi dojść do powiązania myślenia konceptualnego, projektowania i rzemiosła. Dopiero wtedy użytkownicy otrzymają wielofunkcyjny obiekt o nowoczesnym designie. Funkcjonalność jest aktualnie cechą rozpoznawczą designu i wraz z elastycznością staje się atrybutem nowoczesnego wnętrza.

Design - obecnie bardzo modny - tworzy nową jakość. Wcześniej ograniczony, wręcz zamknięty w murach pracowni bądź muzeów, dzisiaj przyciąga w miejscach publicznych: księgarnio-kawiarniach, klubach czy bibliotekach. Sprawia, że czujemy się tam zrelaksowani, czujemy puls miasta.

A dobry design tylko temu służy - miękkie, pluszowe fotele, drewniane krzesła i stoliki z fabryki Thonetta lub z pchlego targu, huśtawka podwieszona w samym centrum księgarni tworzą staroświecki styl i klimat, kopiujący zgrabne domowe pielesze, albo drugi biegun używania designu nowoczesne kryształki skupione wokół żarówek, rozpraszające światło i powiększające przestrzeń, przenośne stoliki na jednej nodze, pufy w wykuszach, minimalistyczne fotele i aksamitne materie ${ }^{11}$.

Projektowane wnętrza mają więc oferować pewien luksus, poczucie bycia w „wielkim świecie”, również w małej lokalnej czytelni. We współczesnej bibliotece design jest elementem tworzenia wizerunku. Architekci i projektanci wnętrz stają więc przed problemem, jak wykorzystać design w służbie bibliotekom, jakich użyć technologii, by wprowadzić

10 M. Pawłowska, Wpływ architektury i aranżacji przestrzennej biblioteki na jej kulturę organizacyjna, [w:] Kultura organizacyjna w bibliotece. Ogólnopolska konferencja naukowa, Białystok, 4-6 czerwca 2007. Praca zbiorowa, pod red. H. Brzezińskiej-Stec, Białystok 2008, s. 445.

11 A. Weyna, Nowe technologie i design w bibliotekach. „Biuletyn EBIB” [online] 2009, nr 3 [dostęp 31 lipca 2016]. Dostępny w World Wide Web: http://www.ebib. pl/2009/103/a.php?weyna. 
nowoczesność i przyciągnąć czytelników, szczególnie młodszego pokolenia. Czy takim magnesem okażą się zaprojektowane przez Jelte van Geesta fotelo-pufy podążające za właścicielem magnetycznej karty bibliotecznej, czy interaktywne projekty skierowane do najmłodszych czytelników, a może w jeszcze inny, bardziej intrygujący sposób designerzy będą zaskakiwać użytkowników i zachęcać ich do odwiedzin bibliotek ${ }^{12}$ Dlatego w ostatnich latach projektowanie nowych budynków bibliotecznych powierza się najlepszym projektantom i światowym pracowniom architektonicznym ${ }^{13}$. Prawdziwą skarbnicą designerskich talentów jest Dania, gdzie np. w Aarhus działa interdyscyplinarne centrum InteractiveSpaces, skupiające architektów, inżynierów i informatyków zajmujących się tworzeniem nowych koncepcji dla przyszłych interaktywnych przestrzeni. Również uczelnie starają się nadążać za nowymi trendami i proponują słuchaczom zajęcia z designu bibliotecznego (Petersburskie Technikum Technologii Bibliotecznych i Informacyjnych) czy przestrzeni i architektury bibliotek (Instytut Informacji Naukowej i Studiów Bibliologicznych UW ${ }^{14}$.

Jedną z ciekawszych inicjatyw mających promować nowe trendy $\mathrm{w}$ architekturze, designie i wzornictwie bibliotecznym jest konkurs, ogłaszany przez redakcję „American Libraries”, na najciekawszy projekt budynku zarówno pod względem innowacyjnej architektury, jak i wielofunkcyjności - Library Design Showcase. Nagradzane są nie tylko nowe konstrukcje, lecz również ciekawe rearanżacje istniejących obiektów. Nagrody są przyznawane w kilku kategoriach ${ }^{15}$. Poza wymienioną instytucją duży wkład w popularyzację nowych trendów w budownictwie

12 Zob. http://www.jeltevangeest.nl [dostęp 31 lipca 2016]; http://www.youtube. com/watch?v=Fu7XciJi6xY [dostęp 31 lipca 2016].

13 Designerzy/architekci/ firmy: Alvor Aalto (1898-1976), Hans Scharoun (1893-1972), Jacques Herzog (1950-), Pierre de Meuron (1950-), Rem Koolhaas (1944-), James Stirling (1926-1992), Santiago Calatravy (1951-), Norman Foster (1935-), Phillipe Starck (1949-), Karim Rashid (1960-), Marcel Wanders (1963-), sir Terence Conrad (1931-), Tord Boontje (1968-), Claus Bjarrum (1947-), spółka Herzog\&Meuron, firma Lammhults Library Design.

14 Zob. L. S. Berkutova, Bibliotečnyj dizajn kak sostavnaâ čast’obŝej informacionnoj kul'tury sovremennogo specjalista, „Naučnye i Tehničeskie Biblioteki” 2013, nr 1, s. 72-77; Przestrzeń i architektura bibliotek [online] [dostęp 31 lipca 2016]. Dostępny w World Wide Web: http://bit.ly/28ZAp93.

15 Zob. „American Libraries” (2009-2016) [online] [dostęp 31 lipca 2016]. Dostępny w World Wide Web: http://americanlibrariesmagazine.org/. 
bibliotecznym ma również międzynarodowa organizacja europejskich bibliotek naukowych LIBER i funkcjonująca w jej ramach LIBER Architecture Group ${ }^{16}$. Dzięki współpracy architektów i bibliotekarzy nowo powstające gmachy są coraz bardziej funkcjonalne, a dotychczasowe magazyny książek, jakimi były biblioteki, zmieniają się w przestrzeń społeczną, chętnej odwiedzaną przez czytelników, których przyciąga atmosfera miejsca. Stąd też w literaturze pojawia się coraz częściej określenie „biblioteka jako miejsce”, również w sensie przestrzeni fizycznej i budownictwa bibliotecznego. Architekturą biblioteczną zajmuje się także Section on Library Buildings and Equipment działająca w ramach Międzynarodowej Federacji Stowarzyszeń i Instytucji Bibliotekarskich (ang. International Federation of Library Associations and Institutions, IFLA) ${ }^{17}$. Projektanci wnętrz i architekci mogą korzystać również z obszernej literatury dotyczącej projektowania przestrzeni bibliotecznej. Promocją architektury - z uwzględnieniem architektury bibliotecznej zajmuje się także założone w 1999 r. czasopismo „Designboom”, które od 2011 r. ma nawet wersję chińską ${ }^{18}$.

Architektura biblioteczna to pojęcie bardzo szerokie, odnoszące się nie tylko do samego gmachu, ale też i do przestrzeni wewnętrznej, otoczenia budynku, jego funkcjonalności i estetyki. Nowo powstające bądź też rearanżowane konstrukcje bywają niekiedy monumentalne i futurystyczne. Ma się wrażenie, że ich twórcy zapominają, iż biblioteka to przede wszystkim miejsce dla lokalnej społeczności, które powinno być skrojone na miarę ${ }^{19}$. Biblioteki bowiem nie tworzy kosztowny projekt architektoniczny czy luksusowe wyposażenie, ale przede wszystkim lu-

${ }^{16}$ Zob. Liber - Association of European Research Libraries [online] [dostęp 31 lipca 2016]. Dostępny w World Wide Web: http://libereurope.eu/ [dostęp 31 lipca 2016]; A. Walczak, Działalność Liber Architecture Group a użytkownicy biblioteki. W: Biblioteka. Klucz do sukcesu użytkowników, pod red. M. Kocójowej (Publikacje Instytutu INiB UJ; seria III, nr 5) [online] [dostęp 31 lipca 2016]. Dostępny w World Wide Web: http://skryba. inib.uj.edu.pl/wydawnictwa/e05/walczak-n.pdf.

17 Zob. http://www.ifla.org/ [dostęp 31 lipca 2016].

18 Zob. N. Lushington, Libraries designer for users. A 21 st century guide, New York 2002; R. C. McCarthy, Managing your library construction project: a step-by-step guide, Chicago 2007; J. A. Woodward, Countdown to a new library: managing the building project, Chicago 2000; „Designboom” (1999-2016) [online] [dostęp 31 lipca 2016]. Dostępny w World Wide Web: http://www.designboom.com.

${ }_{19}$ Zob. M. Waleszko, Program Beyond Access - inne spojrzenie na projektowanie bibliotek [online]. BABIN 2.0 Bibliografia Analityczna Bibliotekoznawstwa i Informacji 
dzie, którzy mają dostęp do wielofunkcyjnego gmachu o bogatym księgozbiorze i nowych technologiach, którym zapewniono komfort korzystania ze zbiorów. Nowoczesna, funkcjonalna biblioteka ma zapraszać do odwiedzin, przyciągać bogatą ofertą i stanowić przeciwieństwo dawnych muzealnych wręcz placówek.

Miejsca, w których buduje się nowe gmachy, są przeróżne. I tak nowe przestrzenie biblioteczne powstają na terenach parkowych (filie North Beach i Pico bibliotek publicznych San Francisco i Santa Monica), a także na przedmieściach bądź w centrach miast, gdzie wkomponowane są w tkankę miasta i tworzą kompleksy edukacyjne (biblioteka w Kopenhadze ${ }^{20}$ ). Nie zawsze siedziby bibliotek tworzy się od podstaw, niekiedy projektanci wykorzystują idee recyklingu i na cele biblioteczne adaptują opuszczone budynki, miejsca garażowe, stare silosy na zboże, budynki poczty, koszar, dworców, a nawet stajnie. Projekty tego typu realizuje się na całym świecie i cieszą się one coraz większą popularnością ${ }^{21}$. W USA takiemu recyklingowi poddawane są zlokalizowane na przedmieściach i niewykorzystywane wielkopowierzchniowe magazyny lub centra handlowe. Biblioteki zakładane w takich miejscach - ze względu na dużą powierzchnię - są najczęściej obiektami wielofunkcyjnymi. Adaptacja tego rodzaju budynków wymaga zmiany oświetlenia na dzienne i przekształcenia powierzchni użytkowej, np. poprzez obniżenie stropów, zastosowanie ogrzewania podłogowego, wymianę niektórych elementów konstrukcji, oraz dostosowania otoczenia dla innego typu użytkowników poprzez zapewnienie bezpiecznych dojść do budynku, parkingów czy przyjaznego zielonego otoczenia. Biblioteki z „odzysku” nie są, niestety, skrojone „na miarę”. Zapewniają z jednej strony spore

Naukowej [dostęp 31 lipca 2016]. Dostępny w World Wide Web http://babin.bn.org. $\mathrm{pl} / \mathrm{p}=3581$.

20 Zob. M. Mastalski, Król przedmieścia, „Architektura \& Biznes” 2012, nr 12, s. 70-77.

${ }^{21}$ Ciekawe i wykorzystujące dobre praktyki projekty rewitalizacyjne np. Biblioteka Akademii Sztuk Pięknych w Brunszwiku (dawny pawilon Meksyku zbudowany na wystawę EXPO 2000); Biblioteka Publiczna w Luckenwalde (dawny dworzec kolejowy); Biblioteka Uniwersytetu Nauk Stosowanych i Sztuki w Lucernie (uprzednio centrum logistyczne szwajcarskiej poczty); Biblioteka Publiczna w Sienie (Włochy, dla uzyskania większej powierzchni zagospodarowano dodatkowo przylegający do XIII-wiecznego gmachu zabudowany zaułek); Miejska Biblioteka Publiczna w Rumi (pierwsza w Polsce placówka zlokalizowana w czynnym dworcu PKP). 
oszczędności, ale ich twórcy muszą się liczyć z ograniczeniami natury technicznej, które mogą uniemożliwić realizację niektórych zamierzeń projektowych. Innym sposobem na wielofunkcyjność istniejących już bibliotek jest transformacja i rozbudowa ich dotychczasowych siedzib (np. Biblioteka Raczyńskich w Poznaniu, Biblioteka Uniwersytetu im. Alberta Ludwiga we Freiburgu).

Jakie więc wymagania stoją przed przyszłymi projektantami nowoczesnych przestrzeni bibliotecznych? Budynek biblioteki - niezależnie od tego, czy będzie nowy, czy też po rewitalizacji - powinien być dobrze zlokalizowany, przestrzenny, oświetlony światłem naturalnym, ciekawy pod względem wystroju wnętrza, zabezpieczony, przygotowany na różne kategorie czytelników, wielofunkcyjny, efektywny, ekonomiczny, dobrze wyposażony i możliwy do rozbudowy. Priorytetem dla projektantów powinno być dążenie do pokazania tych przestrzeni jako miejsc nowoczesnych, o ciekawej aranżacji. Wnętrze, które nie spełnia oczekiwań użytkowników, może przyczynić się do spadku zainteresowania daną placówką. Wówczas konieczne staje się przearanżowanie przestrzeni w sposób zachęcający do odwiedzin. Nowoczesny design może w takim przypadku wiele zdziałać i wywołać pozytywne reakcje czytelników.

Parametry nowej bądź rewitalizowanej placówki określane są na początku procesu projektowania w programie użytkowym, zawierającym niezbędne informacje o tworzonej przestrzeni. Jest on opracowywany dla danej biblioteki przez bibliotekarzy i stanowi zbiór wytycznych dla architektów realizujących projekt. Rola bibliotekarza w procesie projektowania jest istotna, ponieważ dysponuje on wiedzą w zakresie organizacji przestrzennej biblioteki, jej funkcji i organizacji. Doświadczenie czysto zawodowe to jednak nie wszystko. Powinien orientować się w najnowszych, światowych trendach obowiązujących w budownictwie bibliotecznym, jak i wyposażeniu tego typu placówek, a także mieć wiedzę w zakresie wymogów techniczno-technologicznych ${ }^{22}$. Programy zaś muszą przede wszystkim uwzględniać normy: PN-ISO 11799:2006; PN-ISO 11620: 2012 oraz przepisy prawa budowlanego ${ }^{23}$. Również designerzy,

22 F. Sedlaczek, Bibliotekarz i architekt muszq współpracować, „Przegląd Biblioteczny" 1999, z. 1/2, s. 206-207.

${ }^{23}$ Informacja i dokumentacja - wymagania dot. warunków przechowywania materiałów archiwalnych i bibliotecznych (PN-ISO 11799: 2006); Informacja i dokumentacja wskaźniki funkcjonalności bibliotek (PN-ISO 11620: 2012). 
pracując nad danym projektem, muszą się trzymać swoich własnych założeń projektowych, określanych jako DQM (ang. Design Quality Management). Odnoszą się one nie tylko do technicznych walorów, ale też i tych, które zwiększą atrakcyjność funkcjonalną realizowanego projektu ${ }^{24}$.

Najczęściej dobrze zaaranżowana przestrzeń biblioteczna ma kształt kwadratu bądź grupy kwadratów (Stadtbibliothek Stuttgart, George Peabody Library na Johns Hopkins University w Baltimore). Takie rozwiązania zresztą stosowano już w przeszłości. Charakterystyczny dla nowoczesnych bibliotek wolny dostęp do zbiorów wymusił na projektantach powrót do rozwiązań jednoprzestrzennych. Duża przestrzeń, zorganizowana w sposób klarowny i bezpieczny, zachęca do poruszania się i poszukiwań. Jest tworzona najczęściej właśnie na planie kwadratu bądź okręgu. Ciekawym przykładem tego typu rozwiązań jest Beinecke Rare Book and Manuscript Library na Yale University, gdzie formę kwadratu zastosowano wielokrotnie:

w kształcie placu, na którym postawiono Bibliotekę, w planie jej bryły, przyległego dziedzińca wprowadzonego poniżej linii gruntu, wreszcie w rozwiązaniach wnętrza. Tam, w centralnie ulokowanym kwadracie, znalazły się ciągi komunikacyjne i wieża ze zbiorami. Odstępstwem były szklane moduły elewacji powtarzalnego ośmiokąta foremnego, które jednak obserwowane z pewnego oddalenia, nasilają wrażenie dominacji prostej figury kwadratu ${ }^{25}$.

W aranżowanych przestrzeniach bibliotecznych często pojawiają się przeszklone fasady, atria, clerestoria dające wrażenie otwartości, transparentności oraz zewnętrzne patia, altany, ogrody. Ciekawym przykładem są projekty fińskiego architekta Alvara Aalto (w Rovaniemi, Viipuri, Oregonie, Wyburgu), które:

są świetliste, proste, regały nie tworzą skupiska mebli w środku budynku, tylko łagodnie okalają ściany bibliotek, podkreślając w ten sposób linię budynku i niejako otwierając się na czytelnika, nie przygniatając go

${ }^{24}$ Zob. M. Rosińska, dz. cyt., s. 100-101.

25 T. Kruszewski, Przestrzenie bibliotek. O symbolicznej, fizycznej i społecznej obecności instytucji, Toruń 2012, s. 344. 
ogromem zbiorów. Aalto chciał, aby jego budynki odwzorowywały ideę biblioteki jako świątyni wiedzy - traktował to trochę dosłownie, więc blaty biblioteczne wiją się łagodnymi kształtami, formy są proste, trochę ołtarzowe, kolory stonowane, bo panuje biel, czerń, brąz, co koresponduje $\mathrm{z}$ wykorzystaną materią (drewno) ${ }^{26}$.

Szkło dające poczucie otwartości, optycznie powiększające przestrzeń, wykorzystali w swych projektach również polscy twórcy, m.in. w Mediatece START-META w Warszawie czy Bibliotece Uniwersytetu Warszawskiego.

Architekci, projektując przestrzenie biblioteczne, muszą również zaplanować układ szlaków komunikacyjnych dostępnych dla użytkowników. Na ich ostateczny kształt mają wpływ nie tylko realizowane przez bibliotekę zadania i zalecenia inżynierów, ale w dużej mierze pomysły designerów. Ciekawy sposób na ich wyznaczenie zaproponowali twórcy Mediateki ulokowanej w dawnych magazynach w Strasburgu (Médiathègue André Malraux). W tym celu wykorzystali główny element dekoracji, czerwoną wstęgę, która wiła się od wejścia przez dostępne przestrzenie. Czytelnik wybierał więc drogę całkowicie intuicyjnie. Czytelne oznakowanie nawiązywało w tym przypadku do aranżacji i charakteru całego wnętrza.

W nowoczesnej architekturze bibliotecznej znajdują również odzwierciedlenie modne obecnie motywy ekologiczne. I tak mamy fontanny, ogrody, ale również otwarte schody, szklane ściany, antresole i inne elementy przepuszczające światło. Ciekawym przykładem jest Library na Tama Art University w Tokio, która miała pierwotnie znaleźć się pod ziemią, ale:

ostatecznie jej podstawą stała się nierówna linia gruntu. Pochyła podłoga we wnętrzu, odpowiadająca spadkowi ziemi, nie jest jedynym odniesieniem ekologicznym. Ciągłość przestrzeni wewnętrznej i zewnętrznej, pozwalająca na czerpanie energii z natury, zasygnalizowano ponadto układem kopuł i łuków, mających oddawać podziemną przestrzeń. Efekt sztucznej przyrody, widoczny w innych architektonicznych krzywiznach: pomieszczeń, okien i pozostałych otworów, przejawia się też w wyposaże-

${ }^{26}$ A. Weyna, dz. cyt. 
niu. Obłe kształty regałów, ławek, kanap, stołów i pulpitów w czytelni nowych nabytków oraz w czytelni multimedialnej morfologicznie łączą się $\mathrm{z}$ otoczeniem ${ }^{27}$.

Również na naszym gruncie można znaleźć nowoczesne budynki biblioteczne, nawiązujące swą architekturą do środowiska naturalnego oraz tradycji (Centrum Informacji Naukowej i Biblioteka Akademicka w Katowicach). „Rudzielec” z Katowic ma charakterystyczny design w postaci szczelinowych okien ograniczających dostęp światła do wnętrza oraz elewacji wykonanej z czerwonego piaskowca, $\mathrm{w}$ typowej dla śląskich familoków kolorystyce ${ }^{28}$.

Wszystkie dotychczas wymienione elementy architektoniczne składają się na wizerunek biblioteki nowoczesnej, funkcjonalnej. Cechą składową dobrego designu jest także ciekawie zaaranżowane wnętrze. Meble i inne sprzęty mają ułatwiać korzystanie z zasobów i pozytywnie wpływać na komfort pracy użytkowników i bibliotekarzy. Wobec tego wyposażenie stanowić będą nie tylko tradycyjne stoły i krzesła, ale także kanapy i fotele dające chwilę relaksu. Wcześniej tego rodzaju siedziska można było spotkać w bibliotekach dla dzieci. Szybko spodobały się starszym użytkownikom, co znacznie podniosło frekwencję w placówkach, które je wprowadziły. Wygoda może więc współgrać z dekoracyjnością, co potwierdzają wnętrza trzech haskich bibliotek: Bibliotheek Moerwijk, Bibliotheek Seybroek, Bibliotheek Wayeningen. Kolejnym ciekawym elementem aranżacji są regały biblioteczne. W niektórych placówkach mają ażurową konstrukcję, co zdecydowanie nadaje im lekkości, w innych zaś są drewniane. Mogą być wyposażone w przegródki, wsporniki do książek, czasopism i innych dokumentów, z kartą informacyjną na każdym module, przestawnymi co $50 \mathrm{~mm}$ półkami. Ich właściwy dobór umożliwia komfortowe zaaranżowanie przestrzeni.

Nowoczesne placówki, jeśli chodzi o aranżację, wyróżnia prostota i jednocześnie polifunkcyjność. Realizują one zadania edukacyjne oraz kulturalno-społeczne. Dlatego konieczne jest zapewnienie użytkownikom wolnego dostępu do zbiorów, do zamkniętych przestrzeni, w któ-

27 T. Kruszewski, dz. cyt., s. 345.

${ }^{28}$ Zob. M. Tomczak, Rudzielec z Katowic, „Architektura \& Biznes” 2012, nr 12, s. $60-69$. 
rych można zorganizować szkolenia, jak również do kawiarni, pokoi dla dzieci, przestrzeni wystawowych. I właśnie wygoda użytkowników decyduje o atrakcyjności danej biblioteki, a ciekawie zaaranżowana przestrzeń niewątpliwie bardzo w tym pomaga. Niektóre projekty wywołują u użytkowników zachwyt i zdają się prawdziwymi dziełami sztuki ${ }^{29}$. Ciekawy, designerski budynek przyciąga też większą liczbę gości i buduje prestiż nie tylko biblioteki, ale i całego otoczenia.

Należy pamiętać, że biblioteki również się starzeją. Tempo zmian wiąże się nie tylko z szybkością, z jaką powiększają się zbiory i wzrasta liczba użytkowników. Z biegiem czasu dotychczasowy design staje się mało atrakcyjny (np. czytelnia w Central Library Hampstead w Londynie). Poza tym i w tej dziedzinie mamy do czynienia z modą na pewne materiały (np. obecnie stosuje się różnego rodzaju wykładziny). Tak więc wyposażenie i aranżacja przestrzeni zawsze odzwierciedlają obowiązujące trendy i estetyczne upodobania ludzi. Zmiany w tym zakresie powodują, że metamorfoza dotychczas użytkowanych pomieszczeń staje się koniecznością.

W dzisiejszej dobie biblioteki jako instytucje przeżywają renesans. Ciekawe projekty architektoniczne, rozwiązania techniczne, funkcjonalne i wszelkie inne ułatwienia przyciągają użytkowników. Większość z nich po pierwszej wizycie pozostaje w stałym kontakcie z biblioteką. Wbrew obawom, że cyfryzacja może oznaczać ich upadek, są nadal modne, zmieniają się, idą z duchem czasu. Pomaga im w tym innowacyjny design, kreując otaczający nas świat materialny. Współczesny design biblioteczny zakłada pewną elastyczność, jeśli chodzi o pomieszczenia biblioteczne, tak by łatwo można przekształcić część magazynową w wielofunkcyjną przestrzeń. Wyróżniających się ciekawą architekturą wielofunkcyjnych gmachów bibliotecznych powstało w ostatnich latach

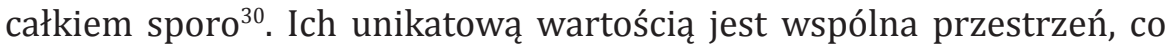

${ }^{29}$ Dobrymi przykładami są np.: Bibliotheca Alexandrina (Aleksandria, 2002, projekt Snøhetta), Staatsbibliothek zu Berlin (Berlin, 1978, projekt Hans Scharoun), Det Kongelige Bibliotek (Kopenhaga, 1999, projekt M. Schmidt, J. E. Larsen), Bibliothèque Nationale de France (Paryż, 1996, projekt Dominique Perrault).

${ }^{30}$ Zob. Biblioteka i dom kultury w Vennesla, Biblioteka Uniwersytecka w Aberdeen, Biblioteka w Kopenhadze, Biblioteka Publiczna w Birmingham, Idea Store Whitechapel, Bibliothek Stuttgart, Biblioteka Politechniki w Delft, Narodowa Biblioteka Techniczna kampus Czeskich Wyższych Uczelni Technicznych, Sendai Mediatheque, National Library of Sejong City by S.A.M.O.O., Biblioteka Hong-Kong University of Science and Technology, 
sprawia, że użytkownicy chętniej je odwiedzają. Poza tym dzięki ciekawemu designowi wzrasta poziom estetyzacji życia.

\section{Wielofunkcyjność nowoczesnych przestrzeni bibliotecznych}

Ten typ biblioteki jest na moją miarę, mogę zdecydować się na to, że spędzę w niej cały dzień pogrążony w świętych rozkoszach; czytam sobie gazety, znoszę książki do baru, potem idę po inne, dokonuję odkryć: przyszedłem, żeby zająć się na przykład angielskim empiryzmem, zaczynam zaś tropić komentatorów Arystotelesa, mylę piętro, wchodzę do działu medycyny, który nie był moim celem, ale potem trafiam nagle na dzieło o Galenie, a więc $\mathrm{z}$ odniesieniami filozoficznymi. $\mathrm{W}$ tym sensie biblioteka staje się przygodą ${ }^{31}$.

Trudno sobie wyobrazić, by świat mógł istnieć bez książek i bibliotek. Czy więc istnieje idealna biblioteka i jaka być powinna: otwarta dla wszystkich czy elitarna? Biblioteka, gdzie w centrum jest człowiek i jemu służy książka, czy biblioteka, gdzie książka jest ważniejsza od czytelnika? Czy nam bliższy jest model opisywany przez cytowanego powyżej Umberta $\mathrm{Eco}^{32}$, czy też Jorge Luisa Borgesa ${ }^{33}$, dla którego:

biblioteka jest kulą, której dokładnym środkiem jest jakikolwiek sześciobok i której obwód jest nieosiągalny. Każdej ze ścian każdego sześcioboku odpowiada pięć szaf; każda szafa zawiera trzydzieści dwie książki znormalizowanego formatu; każda książka posiada czterysta dziesięć stron; każda strona czterdzieści wierszy, każdy wiersz około osiemdziesięciu liter czarnego koloru ${ }^{34}$.

Chińska Biblioteka Narodowa, Seattle Public Library, Joe and Rika Mansueto Library, Biblioteka Jose Vasconcelos, National Library of Latvia.

31 U. Eco, O bibliotece, Wrocław 1990, s. 22-23.

32 Umberto Eco (1932-2016) - włoski filozof kultury, semiotyk, bibliofil, powieściopisarz, autor licznych prac teoretycznych z literatury i kultury. Sławę przyniosła mu powieść Imię róży (1980).

33 Jorge Luis Borgis (1899-1986) - argentyński poeta i prozaik; jeden z najwybitniejszych pisarzy XX w. Opublikował m.in.: Powszechnq̨ historię nikczemności, Fikcje, Alef, Księgę piasku.

34 J. L. Borges, Biblioteka Babel, [w:] tenże, Fikcje, Warszawa 1972, s. 65-66. 
Niezależnie jednak od tego, który model wybierzemy, najważniejsza i tak pozostanie potrzeba obcowania z tekstem pisanym, jako ta jedna z najbardziej elementarnych. Misja i funkcja bibliotek zmieniała się na przestrzeni wieków w zależności od intelektualnego i politycznego klimatu każdej epoki. W XX w. biblioteki często traktowano jako instrumenty społecznej i administracyjnej kontroli, miejsca udostępniania właściwych lektur, ale już w XXI w. ich rola się zmieniła. Obecnie jednym z ich zadań jest opracowywanie projektów skierowanych do szerokiego grona odbiorców. Są kreatywnymi miejscami rozwoju i zdobywania wiedzy, inspirują użytkowników i zapraszają do odwiedzin, oferują udział w interesujących i nietuzinkowych spotkaniach. Sprawnie łączą „zarządzanie organizacją z zarządzaniem przestrzenią"35. W pogoni za czytelnikiem nie zapominają jednak o swej odwiecznej roli - miejscu, gdzie w ciszy można pogłębiać wiedzę, nie uciekając do świata nowoczesnych technologii.

Jeszcze w połowie lat 90. XX w. prognozowano, że zostaną zastąpione bibliotekami wirtualnymi. Jednak tak się nie stało, a za sprawą nowych funkcji, jakie oferują, są z roku na rok popularniejsze i - co ważne - jest to trend światowy. Przeróżne możliwości uczenia się, tworzenia i wymiany wiedzy, jakie zapewniają, byłyby niemożliwe w wirtualnej rzeczywistości. Nowo powstające obiekty gwarantują nie tylko dostęp do nowych technologii, lecz również bogatą ofertę edukacyjną, kulturalną (zob. np. Seattle Central Library, Biblioteka Główna Birmingham, Multimedia Space w Aarhus). Dla bibliotekarzy możliwość łączenia funkcji stała się kluczem do sukcesu. Najłatwiej do zmieniającego się otoczenia dostosowują się biblioteki dla najmłodszych. Ich wnętrza są nierzadko prawdziwymi placami zabaw (Carmel Clay Public Library, Lancaster Veterons Memorial Library, Maribelle M. Davis Library w Plano).

Nowoczesna biblioteka służy często jako katalizator zmian i miejskiego rozwoju (funkcja miejsca), wspiera kreatywność i innowacje, zapewniając przestrzeń dla doświadczeń i nowych spotkań (funkcja przestrzeni), a także ma wkład w synergiczność działań, powiązania i transformacje poprzez nowe, twórcze partnerstwa (funkcja relacji). Przestrzeń biblioteczna, zakotwiczona w środowisku wielkomiejskim,

35 Bibliotekarstwo, pod red. A. Tokarskiej, s. 681. 
w aspekcie kulturowym, jest więc nie tylko kontynuatorką dziedzictwa, ale i kreatorką przyszłości ${ }^{36}$. Zresztą samo pojęcie przestrzeni może być rozpatrywane w różnych aspektach w zależności od tego, czy patrzymy z perspektywy nauk humanistycznych, urbanistyki bądź nauk społecznych. Nowoczesna przestrzeń biblioteczna powinna być wielofunkcyjnym ośrodkiem informacyjnym (w myśl idei one stop shop), który wtapia się w życie lokalnej społeczności i przekształca przestrzeń miejską tak, by miała jak najkorzystniejszy wpływ na lokalne społeczności, zmieniała wizerunek miasta/dzielnicy, wzbogacając środowisko kulturowe i społeczne w ramach rewitalizacji opartej na kulturze. Nierzadko staje się ona symbolem swojego miejsca, jak Universiteitsbibliothek Utrecht-Uithof. Pomocą w zrozumieniu lokalnych potrzeb służy bibliotekom np. międzynarodowa organizacja pozarządowa IREX, która w ramach programu Beyond Access oferuje m.in. pomoc w zakresie szkolenia pracowników, rearanżacji przestrzeni bibliotecznej przy znoszeniu barier (fizycznych, informacyjnych, technologicznych).

Współczesne biblioteki są najczęściej multimedialnymi centrami edukacyjnymi, w szczególności biblioteki akademickie. Koncepcja biblioteki połączonej z centrum edukacyjnym pochodzi ze Stanów Zjednoczonych, a europejskie korzenie ma w Angliii ${ }^{37}$. W USA:

w przypadku bibliotek szkół wyższych, postawiono na innowacyjne projekty mające ułatwiać działalność naukową oraz dydaktyczne i technologiczne interakcje, a w przypadku placówek publicznych - kontakty i funkcje społeczne (połączenie pod jednym dachem centrów komputerowych, konferencyjnych, learning commons, miejsc uczenia się i nauczania, przestrzeni spotkań i wydarzeń kulturalnych, stref usługowych i restauracyjnych, ośrodków rekreacji itp.) $)^{38}$.

${ }^{36}$ A. Nowińska, Przestrzeń biblioteczna w aspekcie socjokulturowym [online]. BABIN 2.0 Bibliografia Analityczna Bibliotekoznawstwa i Informacji Naukowej [dostęp 31 lipca 2016]. Dostępny w World Wide Web: http://babin.bn.org.pl/?p=2643.

${ }_{37}$ Zarządzanie bibliotekq. Najnowsze kierunki w bibliotekarstwie brytyjskim. Wybór tekstów, pod red. I. Kempy, T. Wildhardt, Warszawa 1998, s. 223.

38 M. Waleszko, Rok 2014 w architekturze bibliotecznej Ameryki Północnej [online]. BABIN 2.0 Bibliografia Analityczna Bibliotekoznawstwa i Informacji Naukowej [dostęp 31 lipca 2016]. Dostępny w World Wide Web: http://babin.bn.org.pl/?p=3067. 
W amerykańskich bibliotekach powstają tzw. maker space, centra badawcze i miejsca przyjazne twórcom z różnych pokoleń, oferujące dostęp do najnowszych technologii, laboratoriów fotograficznych, studiów produkcji cyfrowych mediów, jak też gwarantujące przestrzeń dla artystów (sale koncertowe, galerie sztuki). Pomysły na przyciągnięcie użytkowników są różne. Jedne biblioteki tak kształtują swoją przestrzeń, by móc wydzielić np. miejsca nieformalnej nauki - kawiarnie (Uniwersytet Sheffield ${ }^{39}$, inne zaś zapraszają użytkowników np. do nocnych odwiedzin, jak Biblioteka Uniwersytetu Warszawskiego, która z sukcesem realizuje projekt BUW dla sów. Niemniej jednak w pogoni za czytelnikiem nie zapomina się o osobach przywiązanych do dawnych tradycji i w tych w pełni nowoczesnych gmachach wyznacza się miejsca, gdzie zakazane jest korzystanie z urządzeń do komunikacji.

Nowoczesna biblioteka jest „biblioteką hybrydową”, zapewniającą miejsce do indywidualnej bądź grupowej pracy, z możliwością odpoczynku w przyjaznym otoczeniu i z szerokim dostępem do inspirujących inicjatyw na gruncie kultury. Poza tym udostępnia użytkownikom urządzenia techniczne (pracownie komputerowe), gwarantuje dostęp do sieci. Ku takiemu postrzeganiu bibliotek, w szczególności publicznych, skłaniała się opracowana w 2010 r. przez duńską Komisję ds. Bibliotek Publicznych w Społeczeństwie Wiedzy koncepcja zakładająca, że biblioteki mają do zrealizowania cztery podstawowe cele: doświadczenie, zaangażowanie, usamodzielnianie i podnoszenie umiejętności oraz innowacje. W zależności od lokalnych potrzeb niektóre, choć wszystkie powinny być realizowane w tym samym gmachu ze względu na uzupełniający się wzajemnie charakter, mogły zostać potraktowane zamiennie (przestrzenie nauki/koncepcja „trzeciego miejsca”/przestrzeń twórcza) ${ }^{40}$.

39 Zob. M. Waleszko, Studiowanie przy herbacie. O znaczeniu nieformalnych przestrzeni do nauki [online]. BABIN 2.0 Bibliografia Analityczna Bibliotekoznawstwa i Informacji Naukowej [dostęp 31 lipca 2016]. Dostępny w World Wide Web: http://babin. bn.org.pl/?p=2608.

${ }_{40}$ Wśród bibliotek realizujących wskazane cele są: Idea Stores - zajęcia edukacyjne dla dorosłych, laboratoria naukowe, programy rozwoju zawodowego (przestrzenie nauki), biblioteki główne Seattle, Amsterdamu, Kopenhagi (koncepcja „trzeciego miejsca”), Meetingpoint@lasipalatsi i „Library10” w Helsinkach, duński Demoteket - zajęcia dla młodych użytkowników, którzy samodzielnie lub z pomocą bibliotekarzy mogą w nich produkować, edytować muzykę, filmy, ziny, organizować koncerty, pokazy itp. (przestrzeń twórcza).Zob. M. Waleszko, Cztery przestrzenie - nowy model biblioteki publicznej [online]. 
Wobec wielofunkcyjności bibliotek największym wyzwaniem, jakie przed nimi stoi, jest zachowanie równowagi między tradycyjnymi a nowatorskimi usługami oraz integracja nowych funkcji z dawną misją. Niekiedy bowiem zakres ich działania jest tak duży, że nie mieszczą się w tradycyjnym określeniu biblioteka, stają się ośrodkami dydaktycznymi, samokształceniowymi i narzędziami multimedialnej łączności ze światem (Centrum Informacji Naukowej i Biblioteka Akademicka w Katowicach, Dolnośląskie Centrum Informacji Naukowej i Ekonomicznej we Wrocławiu).

Skąd więc taka popularność bibliotek w ostatnich latach? Według Sama Damasa ludzie kierują się tym, że biblioteka to miejsce spotkań, uczenia się i nauczania, ma niekomercyjny charakter, zapewnia możliwość prowadzenia badań, rekreacji, znalezienia ciekawych materiałów ${ }^{41}$. Z czasem zaczyna odgrywać istotną rolę w koncepcji „trzeciego miejsca", która zakłada, że:

biblioteka ma pełnić rolę placówki integrującej lokalną społeczność, stanowić trzeci, poza domem i pracą, centralny dla życia lokalnej społeczności ośrodek, w którym skupia się życie towarzyskie, gdzie chce się bywać i gdzie ludzie mogą czuć się swobodnie. Chodzi o stworzenie neutralnej, nieformalnej przestrzeni zachęcającej do spotkań z przyjaciółmi i rodziną, dyskusji, odpoczynku, uczestnictwa w kulturze i realizacji pasji twórczych oraz umożliwiającej wirtualny kontakt z całym światem ${ }^{42}$.

Biblioteka jest najczęściej postrzegana jako placówka o ciekawie zaprojektowanym wnętrzu i otwarta na potrzeby lokalnych społeczno-

BABIN 2.0 Bibliografia Analityczna Bibliotekoznawstwa i Informacji Naukowej [dostęp 31 lipca 2016]. Dostępny w World Wide Web: http://babin.bn.org.pl/?p=1627.

${ }^{41}$ S. Demas, From the Ashes of Alexandra: Whot's Happening in the College Library? W: Library as Place [online]. Washington: Council on Library and Information Resources, 2005 [dostęp 31 lipca 2016]. Dostępny w World Wide Web: http://www.clir.org/pubs/ reports/pub129/demas.html.

${ }^{42}$ Koncepcję „trzeciego miejsca” przedstawił w 1989 r. Ray Oldenburg. R. Oldenburg, The great good place: cafés, coffee shops, bookstores, bars, hair salons, and other hangouts at the heart of a community, Nowy Jork 1999; A. Nowińska, Trzecie miejsce: nowa generacja bibliotek publicznych $w$ Montrealu [online]. BABIN 2.0 Bibliografia Analityczna Bibliotekoznawstwa i Informacji Naukowej [dostęp 31 lipca 2016]. Dostępny w World Wide Web: http://babin.bn.org.pl/?p=2934. 
ści. Jest przestrzenią społeczną, a jej oferta nie zawsze jest propozycją ściśle biblioteczną, lecz może odnosić się do aktywności pozaczytelniczej, do życia społecznego czy kulturalnego. Tomasz Kruszewski pisze, że życie towarzyskie, „które ma kwitnąć w bibliotekach publicznych traktowanych jako tzw. trzecie miejsce, jest takim swoistym systemem «nachodzącym» na obszar biblioteki"43. Dobry przykład stanowią placówki duńskie. Są one tak aranżowane, by ułatwiały:

obcym ludziom zawieranie znajomości, spotykanie się, wspólne spędzanie czasu. Stąd dbałość o przejrzystość architektoniczną obiektów bibliotecznych, możliwość bezpośredniego zaglądania do wnętrza, doskonała widoczność, nawet z odległych punktów miasta, wkomponowanie budynku w ciekawy krajobraz ${ }^{44}$.

Warto szczególnie wspomnieć o jednej z nich, mianowicie o bibliotece publicznej w Hjørring, mieszczącej się w centrum handlowym (projekt: John Gehl). Jest ona miejscem spotkań lokalnej społeczności, zapewnia możliwość pracy intelektualnej, miasto zaś zyskało dodatkową przestrzeń dla inicjatyw kulturalnych. Charakterystyczna czerwona linia (element architektoniczny) łączy poszczególne wnętrza, m.in.: pokój rekreacyjny (wyposażony w urządzenia multimedialne), kawiarnię, kącik edukacyjny dla dzieci, dział dla dorosłych, księgozbiór z wolnym dostępem, kącik dla rodziców ${ }^{45}$. Tak więc użytkownicy bibliotek przestali być kłopotliwym dodatkiem, ale stali się gospodarzem danej przestrzeni, a ich zwiększona liczba świadczy o atrakcyjności danej placówki.

Ośrodki biblioteczne, wpisując się w koncepcję „trzeciego miejsca”, cieszą się taką popularnością również z powodu ciekawie zaaranżowanych wnętrz, gdzie odchodzi się „od sztywnych podziałów na czytelnie, wypożyczalnie, starając się zapewnić przyjazne miejsce do pracy, nauki, odpoczynku, spotkań. Dotyczy to nie tylko projektów sal bibliotecznych, ale również architektury wnętrz, wyposażenia, mebli, roślinności, a więc

43 T. Kruszewski, dz. cyt., s. 406.

${ }^{44}$ M. Pawłowska, dz. cyt., s. 444.

45 A. Piotrowska, M. Witczak, Zastosowanie idei „trzeciego miejsca” na przykładzie wybranych bibliotek europejskich (Hjørring, Blanes) [online]. Repozytorium Uniwersytetu Łódzkiego [dostęp 31 lipca 2016]. Dostępny w World Wide Web: http://dspace.uni.lodz. $\mathrm{pl}$ /xmlui/bits...49-63.pdf?sequence=1\&isAllowed=y. 
tych elementów, które mają zapewnić atrakcyjność miejsca i sprawić, aby biblioteka stała się placówką przyciągającą studentów i innych użytkowników"46. Dodatkowym czynnikiem przyciągającym potencjalnych czytelników jest wspomniany już „wolny dostęp”, dający możliwość swobodnego kontaktu z książką i szansę na znalezienie tytułu, na który nie trafili, przeszukując katalog online. Współczesny czytelnik najczęściej nie porusza się po bibliotece po omacku, ale dobrze zna system biblioteczny i chętnie korzysta z dostępnych ofert. Specjalnie dla użytkowników biblioteki tworzą też jeszcze jeden typ przestrzeni dającej poczucie zadomowienia, tj. place of dwelling. „Miejsce pauza” pozwala na chwilę zatrzymania i wyłączenia z życia codziennego.

Obecnie można mówić o renesansie bibliotekarstwa, a nowe designerskie gmachy służą wszystkim, którzy szukają miejsca pozwalającego na ucieczkę od rzeczywistości. Stanowią część lokalnej społeczności, symbol społecznej i kulturowej edukacji. Niezmiennie są ośrodkami, gdzie można rozwinąć nieszablonowe zainteresowania. Biblioteka współczesna „to odbicie społecznego konsumeryzmu, Baumanowskiej «kultury pośpiechu». Demonstruje zmieniający się status wiedzy, która staje się obiektem gry społecznej, jest ulotna i powierzchowna" ${ }^{47}$. Mimo że biblioteki zmieniały się na przestrzeni dziejów, to ich „duch” pozostał niezmienny. I może będzie tak, jak pisze J. L. Borges w eseju Biblioteka Babel:

Być może zwodzi mnie starość i obawa, ale podejrzewam, że rodzaj ludzki - jedyny - jest na wymarciu i że Biblioteka przetrwa: oświetlona, samotna, nieskończona, doskonale nieruchoma, uzbrojona w cenne woluminy, niezniszczalna, tajemnicza ${ }^{48}$.

\section{Bibliografia}

\section{Publikacje drukowane}

(mk), Wielorybi szkielet z drewna, „Architektura \& Biznes” 2012, nr 12, s. 78-83.

46 D. Konieczna, Biblioteka akademicka jako instytucja promująca proces kształcenia, [w:] Biblioteki naukowe w kulturze i cywilizacji. Działania i codzienność. Materiały konferencyjne (Poznań, 15-17 czerwca 2005), pod red. H. Ganińskiej, Poznań 2005, s. 119.

47 T. Kruszewski, dz. cyt., s. 408.

48 J. L. Borges, dz. cyt., s. 73. 
Barańska Katarzyna, Światło północy, „Architektura \& Biznes” 2012, nr 12, s. 84-87.

Berkutova Lâlâ Sergeevna, Bibliotečnyj dizajn kak sostavnaâ čast' obŝej informacionnoj kul'tury sovremennogo specjalista, „Naučnye i Tehničeskie Biblioteki" 2013, nr 1, s. 72-77.

Bibliotekarstwo, pod red. Anny Tokarskiej, Warszawa 2013.

Bibliotekarstwo, pod red. Zbigniewa Żmigrodzkiego, Warszawa 1998.

Borges Jorge Luis, Biblioteka Babel, [w:] tenże, Fikcje, Warszawa 1972.

Broto Carles, Libraries Innovation and Design, Barcelona 2014.

Campbell James W. P., The Library: A World History, Chicago 2013.

Cudnik Zbigniew, Skarbnice wiedzy. Studium budownictwa bibliotecznego, Wrocław 1980.

Dawson Robert, Patchett Ann, Moyers Bill, The Public Library: A Photographic Essay, Princton 2014.

Della Santa Leopold, Della construzione e del regolamento di una publica uniwersale biblioteca con la pianta dimostrativa, Karl-Marx-Stadt, Technische Hochschule, 1984.

Eco Umberto, O bibliotece, Wrocław 1990.

Eco Umberto, Carrière Jean-Claude, Nie myśl, że ksiq̨żki zniknq, Warszawa 2010.

Encyklopedia wiedzy o książce, kom. red. Aleksander Birkenmajer [et .al.], Wrocław 1971.

Faulkner-Brown Harry, Factors affecting the planning and design of academic libraries, Speakers' notes for The British Council Seminar, [w:] Library planning and design, Newcastle upon Tyne, 11-24 Sept. 1994.

Hammer Bjorne, Libraries (Road Reflections), Dublin 2014.

Hollender Henryk, Kobierska-Maciuszko Ewa, Nowy gmach Biblioteki Uniwersyteckiej w Warszawie. Koncepcja funkcjonalna i estetyczna, „Rocznik Biblioteki Narodowej" t. 32: 2002, s. 195-214.

Höfer Candida, Libraries, with an essay by Umberto Eco, München 2014.

Johnson Alex, Improbable Libraries: A Visual Journey to the World's Most Visual Libraries, Chicago 2015.

Konieczna Danuta, Biblioteka akademicka jako instytucja promująca proces kształcenia, [w:] Biblioteki naukowe w kulturze i cywilizacji. Działania i codzienność. Materiały konferencyjne (Poznań, 15-17 czerwca 2005), pod red. Haliny Ganińskiej, Poznań 2005, s. 111-121.

Konieczna Danuta, Nowe trendy w architekturze i organizacji przestrzeni $w$ bibliotekach polskich, [w:] Nowoczesna biblioteka. Materiały z ogólnopolskiej, 
przedzjazdowej konferencji SBP Konstancin-Jeziorna 29-30.05.2009 r., pod red. Marcina Drzewieckiego, Warszawa 2009, s. 21-33.

Kruszewski Tomasz, Przestrzenie biblioteki. O symbolicznej, fizycznej i społecznej obecności instytucji, Toruń 2012.

Lushington Nolan, Libraries designer for users. A 21 st century guide, New York 2002.

Lushington Nolan, Rudorf Wolfgang, Wong Liliane, Libraries: A Design Manual, Basel 2016.

McDonald Andrew, The Ten Commandments revisited: the Qualities of Good Library Space, "LIBER Quarterly: The Journal of European Research Libraries", Vol. 16: 2006, Iss. 2.

Mastalski Mateusz, Król przedmieścia, „Architektura \& Biznes” 2012, nr 12, s. 70-77.

McCarthy Richard C., Managing your library construction project: a step-by-step guide, Chicago 2007.

Miller Rebecca T., Genco Barbara A., Better Library Design: Ideas from Library Journal, Lanham 2015.

Oldenburg Ray, The great good place: cafés, coffee shops, bookstores, bars, hair salons, and other hangouts at the heart of a community, New York, 1999.

Pawłowska Maria, Wpływ architektury i aranżacji przestrzennej biblioteki na jej kulturę organizacyjna, [w:] Kultura organizacyjna w bibliotece. Ogólnopolska konferencja naukowa, Białystok, 4-6 czerwca 2007. Praca zbiorowa, pod red. Haliny Brzezińskiej-Stec, Białystok 2008, s. 440-456.

Pędich Marcin, Architektura bibliotek. Analiza trendów na podstawie piśmiennictwa zagranicznego rejestrowanego w Bibliografii Analitycznej Bibliotekoznawstwa i Informacji Naukowej, „Przegląd Biblioteczny” 1999, z. 1/2, s. 206-207.

Roth Manuela, Masterpieces: Library Architekture + Design, Salenstein 2014.

Siedlaczek Franciszek, Bibliotekarz i architekt muszq współpracować, „Przegląd Biblioteczny" 1999, z. 1/2, s. 206-207.

Tomczak Małgorzata, Rudzielec z Katowic, „Architektura \& Biznes” 2012, nr 12, s. 60-69.

Woodward Jeannette A., Countdown to a new library: managing the building project, Chicago 2000.

Worpole Ken, Contemporary Library Architecture: A Planning and Design Guide, Londyn 2013. 
Zarządzanie biblioteka. Najnowsze kierunki w bibliotekarstwie brytyjskim. Wybór tekstów, pod red. Igora Kempy, Teresy Wildhardt, Warszawa 1998.

\section{Publikacje elektroniczne}

Konieczna Danuta, Współczesne trendy architektury bibliotecznej a zmieniające się wymagania użytkowników bibliotek. W: Biblioteki XXI wieku. Czy przetrwamy? Materiały konferencyjne. „Biuletyn EBIB” [online]. Materiały konferencyjne; nr 16 [dostęp 31 lipca 2016]. Dostępny w World Wide Web: http://www.ebib.info/publikacje/matkonf/biblio21/.

Nowińska Alina, Przestrzeń biblioteczna w aspekcie socjokulturowym [online]. BABIN 2.0 Bibliografia Analityczna Bibliotekoznawstwa i Informacji Naukowej [dostęp 31 lipca 2016]. Dostępny w World Wide Web: http://babin.bn.org.pl/?p=2643.

Nowińska Alina, Trzecie miejsce: nowa generacja bibliotek publicznych w Montrealu [online]. BABIN 2.0 Bibliografia Analityczna Bibliotekoznawstwa i Informacji Naukowej [dostęp 31 lipca 2016]. Dostępny w World Wide Web: http://babin.bn.org.pl/?p=2934.

Piotrowska Agnieszka, Witczak Magdalena, Zastosowanie idei „trzeciego miejsca" na przykładzie wybranych bibliotek europejskich (Hjørring, Blanes) [online]. Repozytorium Uniwersytetu Łódzkiego [dostęp 31 lipca 2016]. Dostępny w World Wide Web: http://dspace.uni.lodz.pl/xmlui/bits...4963.pdf? sequence=1\&isAllowed=y.

Walczak Anna, Działalność Liber Architecture Group a użytkownicy biblioteki. W: Biblioteka. Klucz do sukcesu użytkowników, pod red. M. Kocójowej (Publikacje Instytutu INiB UJ; seria III, nr 5) [online] [dostęp 31 lipca 2016]. Dostępny w World Wide Web: http://skryba.inib.uj.edu.pl/wydawnictwa/ e05/walczak-n.pdf.

Waleszko Małgorzata, Cztery przestrzenie - nowy model biblioteki publicznej [online]. BABIN 2.0 Bibliografia Analityczna Bibliotekoznawstwa i Informacji Naukowej [dostęp 31 lipca 2016]. Dostępny w World Wide Web: http://babin.bn.org.pl/?p=1627.

Waleszko Małgorzata, Program Beyond Access - inne spojrzenie na projektowanie bibliotek [online]. BABIN 2.0 Bibliografia Analityczna Bibliotekoznawstwa i Informacji Naukowej [dostęp 31 lipca 2016]. Dostępny w World Wide Web http://babin.bn.org.pl/?p=3581. 
Waleszko Małgorzata, Rok 2014 w architekturze bibliotecznej Ameryki Północnej [online]. BABIN 2.0 Bibliografia Analityczna Bibliotekoznawstwa i Informacji Naukowej [dostęp 31 lipca 2016]. Dostępny w World Wide Web: http://babin.bn.org.pl/?p=3067.

Waleszko Małgorzata, Studiowanie przy herbacie. O znaczeniu nieformalnych przestrzeni do nauki [online]. BABIN 2.0 Bibliografia Analityczna Bibliotekoznawstwa i Informacji Naukowej [dostęp 31 lipca 2016]. Dostępny w World Wide Web: http://babin.bn.org.pl/?p=2608.

Weyna Aleksandra, Nowe technologie i design w bibliotekach. „Biuletyn EBIB” [online] 2009, nr 3 [dostęp 31 lipca 2016]. Dostępny w World Wide Web: http://www.ebib.pl/2009/103/a.php?weyna.

\section{Design and Multifunctionality of Modern Library Spaces}

ABSTRACT: The mission and functions of libraries have changed over centuries. Currently, the offer of libraries is targeted to a wide audience. Modern facilities are the most creative places of development and learning that inspire and encourage visits. Their growing popularity is largely a result of interesting design and versatility of their spaces. In recent years, these issues have become the subject of an interesting discussion of library portals, blogs and above all in research literature, both domestic and foreign. I picked up my theme to bring the reader to the new trends in interior space of the library. I try to answer the question where to get the knowledge about it; how libraries should adapt their services to the needs of readers; how to develop a multi-purpose space that becomes attractive; what is the role of the librarian in preparation and implementation of the investment? For example, I refer to a dozen of libraries with interesting equipment, as well as the architecture to illustrate it, which gained global recognition. My main intention is to draw attention to the role of design in creating a unique atmosphere and strengthening the bonds between librarians and readers as well as the change that has taken place in recent years in terms of perception of libraries that have become multifunctional centres, inspiring and inviting to frequent visits.

KEYWORDS: design, library buildings, library space, library users. 